\title{
Influence of diet on occult blood tests'
}

\author{
D. G. ILLINGWORTH \\ From the Clinical Laboratory, Western General Hospital, Edinburgh
}

EDITORIAL SYNOPSIS The importance of dietary control is brought out by this study of orthotolidine (Ames) tests. Forty-three per cent of normal people passed positive stools when the Occultest method was employed with an unrestricted diet compared with $21 \%$ for the Hematest method.

There is a dearth of experiment on the human subject. Test-tube experiments on foodstuffs are helpful, but are not sufficient to allow of dogmatic statements about their dietary influences.

To advise an unrestricted diet and give significance only to strongly positive reactions is an approach with a superficial appeal (Ratnoff, 1923; Alvarez and Wight, 1927; Levin and Watt, 1949; Needham and Simpson, 1952; Mason and Belfus, 1952; Barnett, 1952; Todd, Sanford, and Wells, 1953; Forshaw and Mason, 1954; Smith, 1958; Jones and Gummer, 1960; Cameron, 1960), but such an approach will lead, as is apparent in the work of these authors, to an appreciable number of falsepositive results due to meat in the diet. All other contributors to the literature specify that the diet shall be meat-free but do not define what they mean. Although Dewis (1907), Leech (1907), Mackay (1916) and Gregersen (1917) state that eating fish will not cause false-positive results, there is contrary opinion (Joslin, 1906; White, 1907; Aaron, 1924; Leiboff, 1929; Kiefer, 1934; Gettler and Kaye, 1943; Kolmer, 1943; White and Geschickter, 1948; Kolmer, Spaulding, and Robinson, 1952). Poultry is forbidden by Mackay (1916), by Lipetz (1947), and by Warner (1950) but permitted by Leech (1907) and Bramkamp (1929).

Green vegetables have also provoked contention. Barrett (1936) claims that their inclusion in the diet will tend to produce false-negative results. Other workers believe that green vegetables are permissible (Adler, 1921; Johnson and Oliver, 1941; Kohn and O'Kelly, 1955); but whereas Alvarez and Summerskill (1958) and Winkelman and Summerskill (1961) exclude only spinach from the vegetables in the diet of the patient under test, there are many who prohibit all green vegetables (Stone, 1907; Clark, 1909; Mackay, 1916; Reimann, 1923;

'This article forms part of a thesis for which was awarded the degree of M.D. (with commendation) at Edinburgh University in 1963.
Hurst, 1925; Rosenthal, 1940; Warner, 1950; Hughes, 1952; Douthwaite, 1954; Stubbé, 1958).

Bovril (Douthwaite, 1954) is specifically mentioned as a misleading substance in the diet of patients being assessed.

\section{MATERIALS AND METHODS}

An appraisal was made of the orthotolidine tablet procedures (Ames), one of which, Occultest, is much more sensitive than the other, Hematest (Illingworth, $1965 \mathrm{a}$ and $\mathrm{b}$ ). Initially the faeces passed by a number of people whose alimentary tracts were, as far as could possibly be judged, normal, and who were eating an unrestricted diet (Table I) were tested by these techniques.

Secondly a wide range of foodstuffs was tested using the Occultest and Hematest techniques directly. In addition, as a confirmatory method and clinical yardstick, the classical benzidine test of Schlesinger and Holst (1906) was also employed (Table II). Some guidance was needed as to the rapidity and intensity of the reaction, and to this end, if the blue colour, denoting a positive reaction, appeared within 60 seconds, the result was recorded as +++ ; if within 90 seconds as ++ ; if within 120 seconds as + .

Thirdly, on completion of the direct experiments with foodstuffs, it was felt that one could not, without further investigation, accept that foodstuffs which gave a strong positive reaction when tested directly, would continue to give the same result after passage through the alimentary canal. Accordingly, volunteers, living on a diet of eggs, milk, white fish, and wheat, and passing negative stools, when tested with Occultest, Hematest, and benzidine methods, consumed various articles of food which, in vitro, gave positive results (Table III).

Finally, in accordance with the results of these tests, a diet sheet was compiled which was expected to have the effect of producing negative specimens of stool in a normal person. This diet was imposed on 75 subjects who had no evidence of gastrointestinal disease. The Occultest and Hematest techniques were then performed on stools obtained from each subject on the first, third, fourth, and fifth days of dietary control (Table IV). 
RESULTS AND DISCUSSION

The results of the examination of the faeces of 126 normal people, eating an unrestricted diet (Table I), show that $43 \%$ of these subjects passed specimens which gave a positive Occultest reaction. Twenty-one per cent of the subjects also showed a positive Hematest reaction in their faeces. Such figures, of course, are in accordance with the manufacturer's belief that the Hematest is a much less sensitive test than the Occultest.

\section{TABLE I}

RESULTS OF OCCULTEST AND HEMATEST METHODS ON 126 SUBJECTS WITHOUT EVIDENCE OF ALIMENTARY DISEASE AND ON FULL DIET

\begin{tabular}{ll} 
Result & No. of Subjects \\
\hline Occultest positive & $54(43 \%)$ \\
Occultest negative & $72(57 \%)$ \\
Hematest positive & $27(31 \%)$ \\
Hematest negative & $99(79 \%)$
\end{tabular}

It is also apparent that, in an unprepared patient, a positive result may be of dietary origin, whichever technique is used.

Bell (1923), using the benzidine test, found that $88 \%$ of people on a normal hospital diet passed faeces giving a positive reaction, whereas with the Guaiac test the figure was $63 \%$. Hughes' (1952) figures were concerned with the number of specimens tested and not with the number of patients studied: no comparative interpretation is therefore possible.

Hepler, Wong, and Pihl (1953) tested the faeces of 80 people without alimentary symptoms, and, using the benzidine method as a test-tube technique, found that $70 \%$ passed positive stools, while with the Hematest tablet the figure was $62 \%$. Hoerr, Bliss, and Kauffman (1949) tested 92 subjects employing various test-tube methods, and the relative percentages were 95 with benzidine, 87 with ortbotolidine, and 22 with the Guaiac test.

Thornton and Illingworth (1955) found that $76 \%$ of the patients, who were on a normal diet and were without evidence of gastrointestinal upset, passed faeces which gave a positive reaction with the benzidine test.

There is a scarcity of experimental work relating to the application of occult blood tests direct to foodstuffs. Schumm and Westphal (1905) recorded that raw potato gives a positive bendizine reaction which is reversed by cooking, and that nuts, peas, milk, flour, and fresh leaves behave in the same way. They believed that boiling the stool specimen would, however, avoid false-positive results from dietary factors. Dewis (1907) believed such action to be unnecessary, noting that the positive results which he obtained from flour, oatmeal, potato, and carrot became negative when such foodstuffs were cooked. Stone (1907) prohibited raw vegetables in his patients' diets, and Leech (1907) claimed that, while unboiled vegetable material oxidized Guaiac, boiled vegetable material did not. Adler (1921), using a concentrated solution of benzidine, had negative results when testing direct such vegetables as peas, potatoes, carrot, and cabbage, but he failed to record whether or not these substances were cooked. Fearon (1946) pointed out that the heat-labile catalyst in unboiled plant extracts will interfere with the tests for occult blood. Peranio and Bruger (1951) may have been unaware of this fact when their Hematest results were occasionally, and unexpectedly, positive. Needham and Simpson (1952), however, noted the reversal produced in the Gregersen test by cooking turnip and potato.

The direct experiments on foodstuffs (Table II) show that in general uncooked or untreated animal or vegetable tissue gives a positive reaction which is reduced or nullified after cooking. Beef and mutton are exceptions, as the diminution of their reacting power is not significant. Nor is game, in particular pheasant, altered to any extent. In the world of fish. salmon and sardines also retain their vigorous peroxidase activity.

TABLE II

RESULTS OF DIRECT EXPERIMENTS ON FOODSTUFFS

\begin{tabular}{llll} 
Foodstuff & Occultest & Hematest & Benzidine \\
\hline Meat & +++ & +++ & +++ \\
Pork & ++ & + & + \\
Chicken & + & + & + \\
Pheasant & +++ & +++ & +++ \\
White fish & - & - & - \\
Salmon & +++ & +++ & +++ \\
Sardines & +++ & +++ & +++ \\
Soup (meat) & +++ & +++ & +++ \\
Bovril (concentrated) & - & - & - \\
Marmite (concentrated) & - & - & - \\
Milk (raw) & - & - & - \\
Cabbage (raw) & ++ & + & - \\
Cabbage (cooked) & - & - & - \\
Lettuce (raw) & ++ & + & - \\
Lettuce (cooked) & - & - & - \\
Turnip: yellow (cooked) & ++ & ++ & + \\
Turnip: white (cooked) & - & - & -
\end{tabular}

With regard to living things it is apparent that the deciding factor is the colour of the flesh. Pale flesh, such as pork, chicken, and white fish, becomes when cooked only slightly active or inactive when tested by the orthotolidine tablet methods or the benzidine method. Dark flesh-beef, pheasant, salmon, or sardines-retains its potent power to oxidize the chromogenic substrates, in spite of the action of heat. 
In the vegetable kingdom the effect of heat on peroxidase is, generally, as one would expect. All green vegetables, potato, carrot, and oatmeal give a positive reaction in the raw state, which is nullified by cooking. Compared with other vegetable tissue, the peroxidase content of the yellow turnip is especially high, and its reaction is comparable with that of blood. The paler flesh of the white turnip has a much lower peroxidase content which is destroyed by cooking.

Strawberries and raspberries, even in the uncooked state, have no peroxidase action whatever, and differ in this respect from apples, oranges, and bananas. Contrary to the views of Douthwaite (1954), Bovril has no blood-like reaction and may be allowed in the diet. Even Oxo is permissible if the benzidine test is favoured.

The direct experiments on foodstuffs indicate that the diet of a person who is being investigated for occult blood loss should not contain dark flesh, i.e., beef, mutton, game, or fish other than white fish. Nor is it permissible to consume any dish prepared therefrom, such as soup. It is also prudent to forbid raw vegetables as opposed to those which are cooked. Yellow turnip even when cooked is a potential source of false-positive reactions and must be prohibited. The imposition of this special diet has not been found a hardship.

\section{TABLE III}

EFFECT OF CERTAIN FOODSTUFFS ON THE FAECES OF VOLUNTEERS ON A LOW-PEROXIDASE DIET

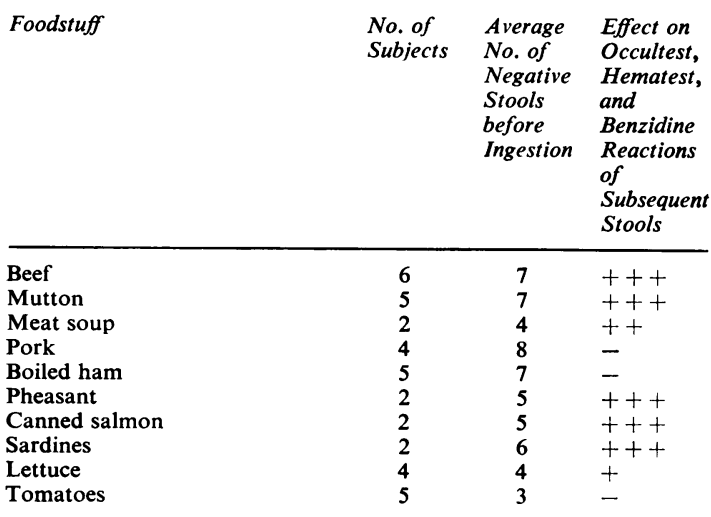

With regard to the timing and frequency of specimens for examination with orthotolidine tablet methods, the conclusion is apparent in Table IV that specimens obtained on the third day of dietary preparation may give a false-positive result due to previous ingestion of certain foods. Therefore, in making a clinical investigation of patients, emphasis
TABLE IV

RESULTS OF EXAMINATION OF FAECES OF 75 NORMAL SUBJECTS ON THE SPECIFIED DIET

\begin{tabular}{lllll} 
& \multicolumn{5}{l}{ Day } \\
\cline { 2 - 5 } & 1 & 3 & 4 & 5 \\
\hline $\begin{array}{l}\text { Number of patients passing Occultest-positive } \\
\text { stools }\end{array}$ & 36 & 15 & 0 & 0 \\
$\begin{array}{l}\text { Number of patients passing Hematest-positive } \\
\text { stools }\end{array}$ & 22 & 4 & 0 & 0
\end{tabular}

stools

should be laid on the specimens obtained on the fourth and fifth days of the special diet.

\section{SUMMARY}

The literature concerning the effect of diet on faecal occult blood tests is reviewed. The dietary factor in the modern orthotolidine tests (Ames) is assessed. Forty-three per cent of normal people passed positive stools when the Occultest method was employed and the diet was unrestricted. The comparable figure for the Hematest method was $21 \%$.

Dark tissue, whether meat, fish, fowl, or vegetable, tends to produce positive tests for occult blood in vitro and in vivo.

A diet is described for patients under investigation.

Faecal specimens should not be tested until the fourth day of dietary preparation.

\section{APPENDIX}

\section{DIRECTIONS TO THE PATIENT}

The doctor proposes to examine your bowel motions and it is important for you to diet in strict accordance with the instructions below.

Begin the diet now and on the first, third, fourth, and fifth days thereafter collect a small piece of each day's motion and place it with toilet tissue in a metal, plastic, or glass container with a close fitting lid. If you cannot pass a daily motion collect the first three motions available from the third day onwards.

Label the containers with your name and the date. Bring them to the doctor after the last of the four motions has been passed and then resume your normal diet.

INSTRUCTIONS You must not eat the following:

1 Beef, mutton, offal, or food prepared therefrom, such as soup, sausage, or meat pie.

2 Salmon or sardines.

3 Game, such as pheasant, grouse, pigeon, hare, or rabbit.

4 Uncooked vegetables, such as lettuce.

5 Turnip.

You may eat anything else at all, including white fish, chicken, bacon, ham, or pork.

Aspirin and similar medicines should be avoided. If you are in the habit of using aperients, you should contınue to do so. 


\section{REFERENCES}

Aaron, C. D. (1924). Spectroscopic and chemical demonstrations of occult blood in the feces. J. Amer. med. Ass., 83, 741-743.

Adler, E. (1921). Ueber den Nachweis von okkultem Blut in den Fäces. Arch. Verdau.-Kr., 27, 153-190.

Alvarez, A. S., and Summerskill, W. H. J. (1958). Gastrointestinal haemorrhage and salicylates. Lancet, 2, 920-925.

Alvarez, R. S., and Wight, T. H. T. (1929). The Gregersen test. Veterans Adm. med. Bull., 5, 888-890.

Barnett, R. N. (1952). The guaiac test-correlation with clinical findings. Gastroenterology, 21, 540-543.

Barrett, J. F. (1936). Effect of ascorbic acid on the chemical tests for blood. Lancet, 2, 1214.

Bell, J. R. (1923). Occult blood in the faeces. Guy's Hosp. Rep., 73, 20-30.

Bramkamp, R. G. (1929). The benzidine reaction. J. Lab. clin. Med., 14, 1087-1091.

Cameron, A. D. (1960). Gastrointestinal blood loss measured by radioactive chromium. Gut, 1, 177-182.

Clark, A. J. (1909). The detection of blood pigments in the faeces. St Bart. Hosp. Rep., 45, 97-104.

Dewis, J. W. (1907). Comparative tests for occult blood in gastric contents and feces. Boston med. surg. J., 157, 169-181.

Douthwaite, A. H. (1954). French's Index of Differential Diagnosis, 7th ed., p. 114. Wright, Bristol.

Fearon, W. R. (1946). An Introduction to Biochemistry, 3rd ed., pp. 252, 377, 459. Heinemann, London.

Forshaw, J. W. B., and Mason, G. M. (1954). Evaluation of occultblood tests on faeces. Lancet, 2, 470-473.

Gettler, A. O., and Kaye, S. (1943). Phenolphthalin test for the detection of occult blood. Amer. J. clin. Path., tech. suppl., 7, 77-79.

Gregersen, J. P. (1917). Untersuchungen über okkulte Blutung. Arch. Verdau.-Kr., 23, 133-168.

Hepler, O. E., Wong, P., and Pihl, H. D. (1953). Comparison of tests for occult blood in feces. Amer. J. clin. Path., 23, 1263-1272.

Hoerr, S. O., Bliss, W. R., and Kauffman, J. (1949). Clinical evaluation of various tests for occult blood in the feces. $J$. Amer. med. Ass., 141, 1213-1217.

Hughes, A. (1952). A simplified benzidine test, with an evaluation of some faecal occult blood tests. Brit. med. J., 2, 970-975.

Hurst, A. F. (1925). Auxiliary methods of diagnosis-radiological and chemical. Ibid., 2, 879-882.

Illingworth, D. G. (1965a). Influence of iron preparations on occult blood tests. J. clin. Path., 18, 103-104.

- $(1965 \mathrm{~b})$. The choice of occult blood tests in general practice. J. Coll. gen. Practit., 9, 33-44.

Johnson, A. S., and Oliver, E. B. (1941). Effect of ingested iron on tests for occult blood in stools. J. Lab. clin. Med., 26, 727-728.

Jones, F. A., and Gummer, J. W. P. (1960). Clinical Gastroenterology, p. 28. Blackwell, Oxford.

Joslin, E. P. (1906). Progress in gastrointestinal diseases. Boston med. surg. J., 154, 655-657, 679-682, 707-711.

Kiefer, E. D. (1934). Detection of occult blood in feces. Amer. J. Surg., $25,530-535$

Kohn, J., and O'Kelly, T. (1955). An ortho-tolidine method for the detection of occult blood in faeces. J. clin. Path., 8, 249-251.
Kolmer, J. A. (1943). Clinical Diagnosis by Laboratory Examinations, p. 1056. Appleton, New York.

-, Spaulding, E. H., and Robinson, H. W. (1952). Approved Laboratory Technic, 5th ed., p. 265. Lewis, London.

Leech, E. B. (1907). Occult haemorrhage in the gastrointestinal tract. Med. Chron., 46, 281-305, 309.

Leiboff, S. L. (1929). The detection of blood by means of benzidine dihydrochloride. J. Lab. clin. Med., 14, 1187-1191.

Levin, M. B., and Watt, J. Y. C. (1949). A simple benzidine test for occult blood in feces. Rev. Gastroent., 16, 650-651.

Lipetz, S. (1947). The diagnosis of peptic ulcer in general practice. M.D. thesis, University of Edinburgh.

Mackay, R. M. (1916). Some investigations on the detection of occult blood in stools. M.D. thesis, University of Edinburgh,

Mason, E. W., and Belfus, F. H. (1952). Detection of occult blood as a routine office procedure, J. Amer, med. Ass, 149, 1526-1528.

Needham, C. D., and Simpson, R. G. (1952). The benzidine test for occult blood in faeces. Quart. J. Med., 21, 123-133.

Peranio, A., and Bruger, M. (1951). The detection of occult blood in feces including observations on the ingestion of iron and whole blood. J. Lab. clin. Med., 38, 433-445.

Ratnoff, H. L. (1923). Ueber das Vorkommen von okkultem Blut in den Faeces bei Säuglingen und in fruhen Kindesalter. $Z$. Kinderheilk., 34, 340-350.

Reimann, H. A. (1923). The relative value of some of the commonly used methods for the detection of occult blood in the stool. J. Lab. clin. Med., 8, 265-270.

Rosenthal, E. (1940). Diseases of the Digestive System, pp. 39, 98. Kimpton, London.

Schlesinger, E., and Holst, F. (1906). Vergleichende Untersuchungen über den Nachweis von Minimalblutungen in den Faeces nebst einer neuen modifikation der Benzidinprobe. Dtsch. med. Wschr., 32, 1444-1447.

Schumm, O., and Westphal, C. (1905). Ueber den Nachweis von Blutfarbstoff mit Hilfe der Adler schen Benzidinprobe. Hoppe-Seylers. Z. physiol Chem., 46, 510-514.

Smith, R. L. (1958). Faecal occult blood tests without dietary restrictions. Brit. med. J., 1, 1336-1338.

Stone, W. J. (1907). Factors influencing the early diagnosis of gastric carcinoma. Amer. J. med. Sci., 134, 517-527.

Stubbé, L. T. F. L. (1958). Occult blood in faeces after administration of aspirin. Brit, med. J., 2, 1062-1066.

Thornton, G. H. M., and Illingworth, D. G. (1955). An evaluation of the benzidine test for occult blood in the feces. Gastroenterology 28, 593-605.

Todd, J. C., Sanford, A. H., and Wells, B. B. (1953). Clinical Diagnosis by Laboratory Methods, 12th ed., p. 507. Saunders, London and Philadelphia.

Warner, E. C. (1950). Savill's system of Clinical Medicine, 13th ed., p. 360. Arnold, London.

White, B. V., and Geschickter, C. F. (1948). Diagnosis in Daily Practice, p. 333. Lippincott, Philadelphia.

White, F. W. (1907). Value of tests for invisible hemorrhage in diagnosis and treatment of diseases of the digestive organs. J. Amer. med. Ass., 48, 506-515.

Winkelman, E. I., and Summerskill, W. H. J. (1961). Gastric secretion in relation to gastrointestinal bleeding from salicylate compounds. Gastroenterology, 40, 56-63. 